\title{
David Cowling, Les métaphores de l'auteur et de la création littéraire à la fin du Moyen Âge: le cas des ' Grands Rhétoriqueurs'
}

\section{Maria Colombo Timelli}

\section{(2) OpenEdition \\ 1 Journals}

Édition électronique

URL : http://journals.openedition.org/studifrancesi/27296

DOI : 10.4000/studifrancesi.27296

ISSN : 2427-5856

Éditeur

Rosenberg \& Sellier

\section{Édition imprimée}

Date de publication : 31 décembre 2006

Pagination : 583-584

ISSN : 0039-2944

\section{Référence électronique}

Maria Colombo Timelli, « David Cowling, Les métaphores de l'auteur et de la création littéraire à la fin du Moyen Âge: le cas des 'Grands Rhétoriqueurs' », Studi Francesi [En ligne], 150 (L | III) | 2006, mis en ligne le 30 novembre 2015, consulté le 08 novembre 2020. URL : http://journals.openedition.org/ studifrancesi/27296; DOI : https://doi.org/10.4000/studifrancesi.27296

Ce document a été généré automatiquement le 8 novembre 2020.

\section{c)}

Studi Francesi è distribuita con Licenza Creative Commons Attribuzione - Non commerciale - Non opere derivate 4.0 Internazionale. 


\title{
David Cowling, Les métaphores de l' auteur et de la création littéraire à la fin du Moyen Âge: le cas des 'Grands Rhétoriqueurs'
}

\author{
Maria Colombo Timelli
}

\section{RÉFÉRENCE}

DAVID COWLING, Les métaphores de l'auteur et de la création littéraire à la fin du Moyen Âge: le cas des 'Grands Rhétoriqueurs', in «Toutes choses sont faictes cleres par escripture». Fonctions et figures d'auteurs du Moyen Âge à l'époque contemporaine. Études rassemblées par Virginie MINET-MAHY, Claude THIRY et Tania VAN HEMELRYCK, «Les Lettres Romanes», numéro hors série, 2004, pp. 99-111.

1 Éditeur en 2002 de l'échange épistolique connu sous le titre de Douze dames de rhétorique, D.C. analyse ici quelques champs sémantiques exploités par Jean Robertet et George Chastelain pour représenter métaphoriquement l'activité créatrice de l'auteur en général et de l'historiographe en particulier: sont mises à profit des images prises de l'univers quotidien (l'œuvre du forgeron, un tissu, un jardin, un bâtiment) ou mythologique (le combat entre Hector et Achille). Souvent, Robertet réemploie des images utilisées ailleurs par Chastelain, qui peut réagir en s'efforçant de corriger les métaphores laudatives que lui adresse son 'correspondant'. 